\title{
Dampak Faktor Eksternal dan Faktor Internal terhadap Perkembangan Bank Umum Syariah di Indonesia
}

\section{The impact of external and internal factors on the development of Islamic banks in Indonesia}

\section{Luthfiah Nurazlina}

Program Studi D4 Keuangan Syariah, Politeknik Negeri Bandung

E-mail: luthfiah.nurazlina.ksy16@polban.ac.id

\section{Hasbi Assidiki Mauluddi}

Jurusan Akuntansi, Politeknik Negeri Bandung

E-mail: hasbi.assidiki@polban.ac.id

\begin{abstract}
The goal of this study was to determine the impact to which external factors such as GDP growth, inflation and BI interest rate and internal factors such as CAR, FDR and NPF have had an influence on the development of Islamic Banks in Indonesia that represented by the growth of total assets Islamic banks in Indonesia from 2015-2019. This research used a quantitative approach and the data would be analyzed using multiple regression test through panel data regression with partial test and simultaneous test provided by Eviews 10. Considering the results of the simultaneous testing, the study suggests that all variables had an impact on the development of the Islamic Bank. As for the partial test, from the external factors only the BI rate which gives a significant negative impact on the development of Islamic banks and from internal factors there are NPF and FDR which give significant negative impact. It was concluded that GDP, Inflation, and $C A R$ did not affect the development of Islamic Banks in Indonesia.
\end{abstract}

Keywords: GDP, Inflation, BI Interest Rate, CAR, NPF, FDR, Total Assets.

\section{Pendahuluan}

Kondisi perbankan syariah yang berada di Indonesia selalu menampilkan perkembangan tiap tahunnya. Hal ini bisa terlihat pada peningkatan total aset yang terjadi dari setiap tahunnya dan berdasarkan laporan Islamic Financial Services Board yang dipublikasikan pada Juli 2019 aset perbankan syariah Indonesia menempati peringkat ke 9 terbesar di dunia (IFSI, 2019). Selain itu, berdasarkan Global Islamic Finance Report (GIFR) 2019, Indonesia berhasil menempati peringkat pertama dalam Pasar Keuangan Syariah Global (GIFR, 2020). Hal ini dapat berarti bahwa Indonesia melakukan peran yang nyata dalam industri perbankan dan keuangan syariah.

Namun, kenaikan total aset dari tahun ke tahun tidak serta merta membuat pertumbuhan perbankan syariah juga mengalami kenaikan, karena yang sebenarnya terjadi pada saat ini adalah pertumbuhan aset bank syariah di Indonesia sedang mengalami perlambatan (Setiawan, 2018). Hal tersebut dapat terjadi akibat para pelaku industri keuangan sulit untuk mencari nasabah pembiayaan.

Fenomena tersebut dapat menggambarkan bahwa selaku negara yang dikenal sebagai negara bermayoritas muslim di dunia, perkembangan perbankan syariah yang berada di Indonesia masih tergolong lambat. Artinya, kontribusi bank syariah terhadap perekonomian di Indonesia masih terbilang rendah sehingga menyebabkan perbankan syariah belum bisa menjadi solusi bagi berbagai permasalahan pada perekonomian nasional. 
Tabel 1. Perbandingan Pangsa Pasar Perbankan Konvensional dan Perbankan Syariah

\begin{tabular}{|c|c|c|c|c|c|}
\hline \multirow[b]{2}{*}{ Tahun } & \multicolumn{3}{|c|}{ Total Asset } & \multicolumn{2}{|c|}{ Market Share } \\
\hline & $\begin{array}{c}\text { Perbankan } \\
\text { Konvensional }\end{array}$ & $\begin{array}{c}\text { Perbankan } \\
\text { Syariah }\end{array}$ & $\begin{array}{c}\text { Perbankan } \\
\text { Nasional }\end{array}$ & $\begin{array}{c}\text { Perbankan } \\
\text { Konvensional }\end{array}$ & $\begin{array}{c}\text { Perbankan } \\
\text { Syariah }\end{array}$ \\
\hline 2014 & Rp 5.705.028 & $\mathrm{Rp} 272.343$ & Rp 5.977.371 & $95,44 \%$ & $4,56 \%$ \\
\hline 2015 & $\operatorname{Rp} 6.197 .621$ & Rp 296.262 & $\operatorname{Rp} 6.493 .883$ & $95,44 \%$ & $4,56 \%$ \\
\hline 2016 & $\operatorname{Rp} 6.843 .300$ & Rp 356.504 & Rp 7.199.804 & $95,05 \%$ & $4,95 \%$ \\
\hline 2017 & Rp 7.513.579 & Rp 424.181 & Rp 7.937.760 & $94,66 \%$ & $5,34 \%$ \\
\hline 2018 & $\mathrm{Rp} 8.204 .039$ & $\mathrm{Rp} 477.327$ & $\mathrm{Rp} 8.681 .366$ & $94,50 \%$ & $5,50 \%$ \\
\hline 2019 & Rp 8.712.597 & Rp 524.564 & Rp 9.237.161 & $94,32 \%$ & $5,68 \%$ \\
\hline
\end{tabular}

Perbandingan pangsa pasar aset bank umum syariah dengan bank konvensional sendiri perbedaannya sangat jelas terlihat. Jaya (2001) menyatakan bahwa pangsa pasar umumnya akan berpengaruh apabila nilainya mencapai 15\%. Berdasarkan Tabel 1. dapat terlihat bahwa pangsa pasar perbankan syariah masih jauh dari angka 15\% sehingga dapat dikatakan bahwa perbankan syariah masih belum bisa memberikan kontribusi yang signifikan akan kondisi perekonomian di Indonesia.

Pengaruh kondisi perekonomian sangat berhubungan dengan kegiatan operasional perbankan Syariah (Tripuspitorini \& Setiawan, 2020). Perbankan syariah dalam melakukan operasionalnya secara langsung bersentuhan dengan sektor riil, sehingga keterkaitan antara perbankan syariah dengan perkembangan lingkungan makro ekonomi sebagai upaya mengembangkan perbankan syariah dan lembaga keuangan syariah perlu diperhitungkan untuk mewujudkan dan menjaga kondisi makro ekonomi yang stabil (Suadi \& Candra, 2016). Tiga variabel yang paling penting dalam mengetahui kondisi makroekonomi tersebut diantaranya: produk domestik bruto, tingkat inflasi, dan BI rate (Mankiw, 2007).

Selain faktor makro ekonomi, faktor internal juga dapat mempengaruhi perkembangan bank syariah. Faktor internal tersebut menurut segi kinerja manajemen bank yang dapat digunakan diantaranya yaitu Capital Adequacy Ratio (CAR), Non Performing Financing (NPF) serta Financing to Deposit Ratio (FDR).

Penelitian mengenai faktor eksternal serta faktor internal akan perkembangan bank umum syariah yang berada di Indonesia sudah sering dilakukan penelitian namun pada hasil yang ditemukan pada penelitian yang satu dengan yang lainnya belum menunjukkan kesinambungan. Hasil dari penelitian Oktavianti dan Nanda (2019) mengungkapkan bahwa adanya pengaruh positif signifikan pada inflasi terhadap pertumbuhan perbankan syariah, sedangkan menurut Hendratno dan Winarno (2019), inflasi tidak menghasilkan pengaruh terhadap pertumbuhan perbankan syariah baik secara parsial maupun simultan. Oktavianti dan Nanda (2019) juga meneliti tentang pengaruh PDB dan Suku Bunga akan pertumbuhan perbankan syariah dan menghasilkan bahwa PDB dan suku bunga berpengaruh negatif signifikan. Sedangkan pada penelitian Hastari (2019) ditemukan pengaruh positif signifikan pada PDB akan ROA bank syariah. Suku bunga juga terdapat pengaruh positif signifikan akan kinerja keuangan perbankan syariah di Indonesia menurut Rahmi (2016).

Pada faktor internal yang dilakukan penelitian oleh Suryakusuma dan Wahyuni (2018) ditemukan ada pengaruh positif signifikan pada variabel CAR akan kinerja keuangan umum bank syariah, sedangkan menurut hasil penelitian Setyawati (2015) CAR mempunyai pengaruh negatif signifikan akan pertumbuhan total aset bank umum syariah. Variabel FDR dan NPF pada penelitian Setyawati (2015) diterangkan bahwa FDR mempunyai pengaruh negatif tidak signifikan akan pertumbuhan total aset bank syariah dan NPF mempunyai pengaruh signifikan akan pertumbuhan total aset bank syariah. Hasil yang diperoleh bertentangan dengan penelitian yang diteliti oleh 
Djuwita dan Mohammad (2016) dimana pada penelitiannya pengaruh yang diberikan oleh FDR dan NPF kepada total aset merupakan pengaruh positif yang sifatnya signifikan.

Hal tersebut berarti bahwa hasil penelitian yang satu dengan yang lain masih menghasilkan ketidakkonsistenan. Sehingga untuk menambah referensi sebagai upaya meningkatkan peranan perbankan syariah sebagai penopang kemajuan ekonomi syariah di Indonesia, maka topik ini masih menarik untuk dibahas. berikut:

Berdasarkan pemaparan yang telah dilakukan maka diputuskan rumusan masalah sebagai

1. Bagaimana dampak yang diberikan oleh Produk Domestik Bruto (PDB) akan perkembangan bank umum syariah di Indonesia?

2. Bagaimana dampak yang diberikan oleh inflasi akan perkembangan bank umum syariah di Indonesia?

3. Bagaimana dampak yang diberikan oleh suku bunga acuan Bank Indonesia akan perkembangan bank umum syariah di Indonesia?

4. Bagaimana dampak yang diberikan oleh Capital Adequacy Ratio (CAR) akan perkembangan bank umum syariah di Indonesia?

5. Bagaimana dampak yang diberikan oleh Non Performing Financing (NPF) akan perkembangan bank umum syariah di Indonesia?

6. Bagaimana dampak yang diberikan oleh Financing to Deposit Ratio (FDR) akan perkembangan bank umum syariah di Indonesia?

7. Bagaimana dampak yang diberikan oleh faktor eksternal dan faktor internal secara simultan akan perkembangan bank umum syariah di Indonesia.

\section{Kajian Pustaka}

\subsection{Bank Umum Syariah}

Bank syariah yang dikemukakan berlandaskan UU No. 21 Tahun 2008 perihal Perbankan Syariah yang tertera pada pasal 1 yakni bank yang kegiatan usahanya dilakukan mengacu pada prinsip syariah serta berdasarkan jenisnya dibedakan menjadi Bank Umum Syariah dan Bank Pembiayaan Rakyat Syariah.

Soemarso (2005) menyatakan bahwa sumber daya perusahaan dalam melakukan usahanya dan merupakan bentuk kekayaan yang dimiliki perusahaan disebut dengan aset. Maka dapat diputuskan bahwa aset merupakan suatu bentuk kekayaan yang dapat berfungsi sebagai alat ukur mengenai keadaan pada suatu perusahaan.

\subsection{Faktor Eksternal}

\section{Produk Domestik Bruto}

Sadono Sukirno (1994) di dalam bukunya menerangkan bahwa produk nasional yang dihasilkan dari beberapa faktor produksi yang berada di dalam negeri baik itu warga negara asing ataupun orang asing di dalam negara disebut dengan Produk Domestik Bruto (PDB). PDB dapat dibedakan menjadi 2 (dua) jenis yakni PDB berdasar harga berlaku dan PDB berdasar harga konstan. PDB yang memungkinkan untuk mengetahui pergeseran dan struktur ekonomi disebut PDB berdasar harga berlaku, sedangkan PDB berdasar harga konstan merupakan PDB yang memungkinkan untuk mengetahui pertumbuhan ekonomi setiap tahunnya (Badan Pusat Statistik, 2019). 


\section{Inflasi}

Tingkat harga umum yang mengalami kenaikan pada suatu kondisi tertentu disebut dengan inflasi (Samuelson \& Nordhaus, 2004). Mengacu pada Sadono Sukirno (1994) inflasi adalah suatu proses peningkatan harga yang sedang berlaku yang terjadi pada suatu kondisi ekonomi. Tingkat keparahan inflasi menurut Boediono (1985) dibedakan menjadi beberapa jenis, diantaranya:

1. Inflasi ringan yakni inflasi yang besarannya lebih rendah dari $10 \% /$ tahun

2. Inflasi sedang, yakni inflasi yang terjadi diantara tingkat 10\% hingga 30\%/tahun

3. Inflasi berat, tingkatan inflasi dimana besarnya diantara 30\% sampai 100\%/tahun

4. Hiperinflasi, inflasi yang terjadi apabila nilai persentasenya lebih dari 100\%/tahun

\section{Suku Bunga Acuan Bank Indonesia}

Suku bunga acuan Bank Indonesia yang dikenal dengan sebutan BI rate diyakini sebagai cerminan sikap maupun stance dari sebuah kebijakan moneter. Penetapan kebijakan suku bunga dilakukan oleh otoritas moneter yakni Bank Indonesia dan hasilnya akan disebarluskan kepada publik (Bank Indonesia, 2016). Suku bunga menjadi komponen paling penting dalam variabel. makroekonomi, karena suku bunga dapat berperan sebagai harga yang dapat menautkan masa kini dan masa akan datang (Mankiw, 2009).

\subsection{Faktor Internal}

\section{Capital Adequacy Ratio (CAR)}

Capital Adequacy Ratio (CAR) diyakini sebagai rasio yang mempunyai kaitan atas faktor permodalan bank yang digunakan sebagai ukuran dalam menghitung cukup atau tidaknya modal yang dipunyai oleh bank sebagai penunjang aktiva yang siftanya berisiko. Zainul Arifin (2009) menyatakan bahwa dalam mengukur tingkat kecukupan modal dapat dilakukan dengan:

1. Melakukan perbandingan antara modal serta dana-dana pihak ketiga

2. Melakukan perbandingan antara modal serta aktiva yang sifatnya berisiko

\section{Non Performing Financing}

Bersumber dari PBI No. 13/23/PBI/2011 risiko kredit merupakan risiko kegagalan pemenuhan kewajiban yang dapat terjadi ketika nasabah atau pihak lain tidak bisa memenuhi perjanjian yang telah diputuskan (Bank Indonesia, 2015). Siamat (2005) memgungkapkan bahwa Non Performing Financing merupakan kesengajaan yang berasal dari faktor internal dan kejadian yang terjadi diluar kendali debitur yaitu faktor eksternal yang dapat menyebabkan kesulitan dalam pelunasan pinjaman.

\section{Financing to Deposit Ratio}

Rasyidin (2016) mengutarakan bahwasanya Financing to Deposit Ratio (FDR) diyakini sebagai rasio yang dipakai untuk mengukur likuiditas bank dalam melakukan pembayaran terkait pengembalian dana yang ditarik oleh nasabah dengan pembiayaan yang diberikan selaku sumber likuiditasnya. Nilai FDR yang semakin tinggi akan membuat perusahaan semakin besar dalam mengahasilkan laba (diasumsikan bank efektif dalam menyalurkan kreditnya, sehingga jumlah kredit macetnya rendah).

\subsection{Kerangka Pemikiran}

Kerangka pemikiran pada penelitian ini dapat diproyeksikan sebagai berikut: 


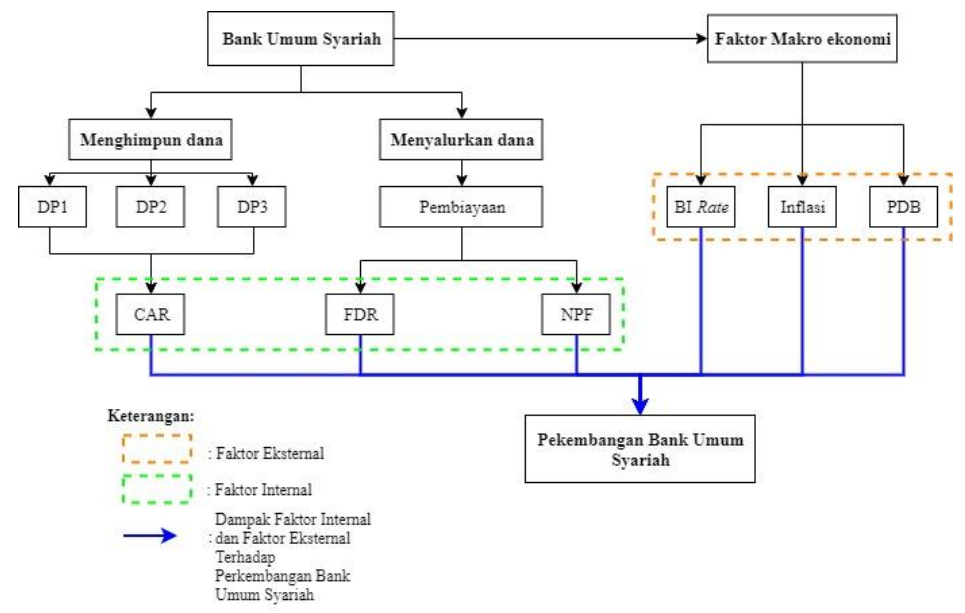

Gambar 1. Kerangka Pemikiran

\section{Metode Penelitian}

Metode penelitian yang diterapkan di dalam penelitian ini berupa metode penelitian kuantitatif. Eviews 10 digunakan sebagai alat analisis dengan jenis analisis berupa regresi data panel. Untuk populasi yang dipakai pada penelitian yang dilakukan merupakan bank umum syariah di Indonesia yang telah berjalan sejak tahun 2015 hingga tahun 2019. Sampel penelitian ditentukan dengan menggunakan purposive sampling menurut kriteria berikut:

1. Merupakan Bank Umum Syariah yang telah berjalan di Indonesia dari 2015-2019.

2. Merupakan Bank Umum Syariah yang menerbitkan laporan keuangan triwulanan dari tahun 2015-2019 yang terdapat pada website bank yang berkaitan.

Terdapat 14 bank umum syariah yang telah beropeasi pada tahun 2019 di Indonesia. Sedangkan di tahun 2015 hanya tercatat 12 bank umum syariah yang telah beroperasi. Maka, menurut kriteria tersebut didapatkan hasil bahwa banyaknya sampel yang dipilih pada penelitian ini yakni 12 bank umum syariah.

Variabel dependen didalam penelitian ini yakni perkembangan bank umum syariah di Indonesia akan direpresentasikan dengan pertumbuhan total aset bank umum syariah. Sementara, untuk variabel independen yaitu faktor eksternal dan faktor internal yang digunakan pada penelitian ini diantaranya yaitu PDB, Inflasi, Suku bunga acuan BI, CAR, FDR dan NPF.

\section{Teknik Analisis Penelitian}

1. Estimasi Regresi Data

2. Teknik Estimasi Regresi Data

3. Uji Asumsi Klasik

4. Uji Kelayakan Model

\section{Hasil dan Pembahasan}

\subsection{Teknik Estimasi Regresi Data}

Setelah melakukan pengujian dengan menggunakan uji chow serta uji hausman, didapatkan model yang terpilih pada penelitian ini yaitu fixed effect model.

\subsection{Uji Asumsi Klasik}

\section{Uji Heteroskedastisitas}

Uji heteroskedastisitas dilakukan dengan membandingkan hasil dari pengujian fixed effect model dengan metode unweighted dan weighted. Berdasarkan hasil perbandingan didapatkan hasil bahwa 
pada FE unweighted terdapat tiga variabel yang hasilnya lebih kecil dari tingkat signifikansi sedangkan pada FE weighted terdapat dua variabel yang hasilnya lebih kecil dari tingkat signifikansi. Hasil Rsquared pada model FE weighted juga terlihat lebih besar (0,378218) (lebih baik) dibandingkan model FE unweighted (0,350906). Karena tidak terdapat perbedaan yang signifikan diantara keduanya maka dapat disimpulkan tidak ditemukannya masalah heteroskedastisitas pada penelitian yang dilakukan.

\section{Uji Multikolinearitas}

Pengecekan uji ini dapat dilihat dengan membandingkan nilai koefisien korelasi dengan nilai $<0,85$. Setelah melakukan pengujian, hasil yang didapat menemukan bahwa tidak ditemukan variabel yang nilai koefisien korelasinya lebih besar dibandingkan 0,85 , maka bisa diputuskan bahwa tidak terdeteksi masalah multikolinearitas pada model ini.

\subsection{Uji Kelayakan Model}

\begin{tabular}{|c|c|c|c|c|}
\hline \multicolumn{5}{|c|}{$\begin{array}{l}\text { Dependent Variable: PERTUMBUHAN_ASET } \\
\text { Method: Panel EGLS (Cross-section weights) } \\
\text { Date: } 07 / 25 / 20 \text { Time: } 09: 12 \\
\text { Sample: } 2015 \mathrm{Q} 12019 \mathrm{Q} 3 \\
\text { Periods included: } 19 \\
\text { Cross-sections included: } 12 \\
\text { Total panel (balanced) observations: } 228 \\
\text { Linear estimation after one-step weighting matrix }\end{array}$} \\
\hline Variable & Coefficient & Std. Error & t-Statistic & Prob. \\
\hline $\mathrm{C}$ & -1.461257 & 30.61517 & -0.047730 & 0.9620 \\
\hline PDB & 2.910433 & 5.676474 & 0.512719 & 0.6087 \\
\hline INFLASI & 0.754804 & 0.671222 & 1.124523 & 0.2621 \\
\hline BI_RATE & -0.139233 & 0.024379 & -5.711270 & 0.0000 \\
\hline CAR & -0.078257 & 0.059345 & -1.318687 & 0.1887 \\
\hline NPF & -0.825108 & 0.174779 & -4.720864 & 0.0000 \\
\hline FDR & $-8.57 E-05$ & 4.14E-05 & -2.069420 & 0.0397 \\
\hline \multicolumn{5}{|c|}{ Effects Specification } \\
\hline \multicolumn{5}{|c|}{ Cross-section fixed (dummy variables) } \\
\hline \multicolumn{5}{|c|}{ Weighted Statistics } \\
\hline R-squared & 0.639386 & \multirow{5}{*}{\multicolumn{2}{|c|}{$\begin{array}{l}\text { Mean dependent var } \\
\text { S.D. dependent var } \\
\text { Sum squared resid } \\
\text { Durbin-Watson stat }\end{array}$}} & 14.50611 \\
\hline Adjusted R-squared & 0.610193 & & & 20.42166 \\
\hline S.E. of regression & 11.78801 & & & 29181.01 \\
\hline F-statistic & 21.90233 & & & 0.704430 \\
\hline Prob(F-statistic) & 0.000000 & & & \\
\hline \multicolumn{5}{|c|}{ Unweighted Statistics } \\
\hline R-squared & 0.586289 & \multirow{2}{*}{\multicolumn{2}{|c|}{$\begin{array}{l}\text { Mean dependent var } \\
\text { Durbin-Watson stat }\end{array}$}} & 9.876009 \\
\hline Sum squared resid & 30742.42 & & & 0.711901 \\
\hline
\end{tabular}

Gambar 2 Hasil Pengujian Menggunakan Fixed Effect Model

\section{a. Uji Hipotesis}

\section{Uji-t}

\section{Variabel PDB terhadap Perkembangan Bank Umum Syariah}

Besar t-hitung untuk variabel PDB adalah sebesar 0,512719 serta probabilitas senilai 0,6087. Hasil tersebut menghasilkan nilai t-tabel $(1,65)$ lebih besar dibandingkan jnilai t-hitung seraya nilai probabilitas lebih besar dari 0,05 maka dapat diputuskan bahwa tidak terdapat pengaruh signifikan pada variabel PDB terhadap perkembangan bank umum syariah maka hipotesis 1 ditolak.

\section{Variabel Inflasi terhadap Perkembangan Bank Umum Syariah}

Besar t-hitung yang diperoleh variabel inflasi menunjukan hasil sebesar 1,124523 dengan probabilitas sebesar 0,2621. Hasil yang diperoleh menunjukkan t-tabel memiliki nilai lebih besar dibandingkan t-hitung serta nilai probabilitas lebih tinggi daripada 0,05 maka bisa diputuskan bahwa pengaruh signifikan tidak dihasilkan oleh variabel inflasi terhadap perkembangan bank umum syariah dan hipotesis 2 ditolak. 


\section{Variabel Suku Bunga Acuan BI terhadap Perkembangan Bank Umum Syariah}

Besar t-hitung pada variabel suku bunga acuan BI memiliki nilai -5,711270 dengan probabilitas 0,0000 . Hasil yang diperoleh menunjukkan bahwa t-tabel lebih kecil dibandingkan thitung serta nilai probabilitas lebih rendah dari 0,05 maka bisa diputuskan bahwa terdapat pengaruh negatif signifikan pada suku bunga acuan BI akan perkembangan bank umum syariah dan hipotesis 3 diterima.

\section{Variabel CAR terhadap Perkembangan Bank Umum Syariah}

Besar t-hitung pada variabel CAR mendapatkan nilai -1,318687 dengan probabilitas sebesar 0,1887. Hasil yang didapat menunjukkan bahwa nilai t-tabel lebih besar ketimbang t-hitung dan nilai probabilitas lebih besar dari 0,05 sehingga bisa diputuskan bahwa CAR tidak memiliki pengaruh yang signifikan terhadap perkembangan bank umum syariah, maka H4 ditolak.

\section{Variabel NPF terhadap Perkembangan Bank Umum Syariah}

Besar t-hitung pada variabel NPF mendapatkan nilai -4,720864 dengan probabilitas sebesar 0,0000. Hasil yang didapat menghasilkan bahwa nilai t-tabel lebih rendah ketimbang t-hitung dan nilai probabilitas lebih rendah dari 0,05 sehingga bisa dikatakan bahwa pengaruh yang diberikan oleh variabel NPF terhadap perkembangan bank umum syariah merupakan pengaruh negatif signifikan dan $\mathrm{H} 5$ diterima.

\section{Variabel FDR terhadap Perkembangan Bank Umum Syariah}

Besar t-hitung pada variabel FDR mendapatkan hasil -2,069420 dengan probabilitas senilai 0,0397. Hasil yang didapat memperlihatkan bahwa t-hitung lebih tinggi ketimbang t-tabel dan nilai probabilitas lebih rendah dari 0,05 sehingga bisa dikatakan bahwa pengaruh yang diberikan oleh variabel FDR terhadap perkembangan bank umum syariah adalah pengaruh negatif signifikan, maka H6 diterima.

\section{Uji F}

Nilai F-statistic yang didapatkan setelah melakukan pengujian menunjukkan hasil 21,90233 dan nilai probabilitas (F-statistic) senilai 0,00000. Karena nilai probabilitas $<0,05$ serta nilai F-statistic $>$ F-tabel (2,25), maka dapat dijelaskan bahwa factor eksternal dan factor internal dapat mempengaruhi perkembangan bank umum syariah di Indonesia secara serentak/simultan.

\section{b. Koefisien Determinasi}

Besar Adjusted R-squared yang didapat menunjukkan hasil 0,610193. Hal ini berarti bahwa variabel independen sebesar $61,02 \%$ pada penelitian dapat menjelaskan variabel dependen. Sedangkan sisa sebesar 38,98\% lainnya dapat diterangkan oleh variabel lain diluar penelitian.

\subsection{Analisis Regresi} berikut:

Model persamaan regresi yang terbentuk dari hasil pengujian dapat dijabarkan sebagai $\mathrm{PA}=-1,461257+2,910433 \mathrm{PDB}+0,754804$ Inflasi $-0,139233 \mathrm{SB}-0,078257 \mathrm{CAR}-0,825108 \mathrm{NPF}$ $-8,57 \mathrm{E}-05 \mathrm{FDR}$

1. Nilai konstanta sebesar -1,461257 dapat berarti jika variabel bebas (PDB, Inflasi, Suku Bunga, CAR, NPF dan FDR) dianggap tidak ada atau tidak berpengaruh maka akan menurunkan pertumbuhan total aset sebesar 1,461257.

2. Nilai koefisien regresi pada variabel PDB sebesar 2,910433 memiliki arti apabila terjadi peningkatan senilai 1\% pada variabel PDB maka akan meningkatkan pertumbuhan aset bank umum syariah sebesar 2,910433 dengan anggapan variabel lain diduga tetap.

3. Pada variabel inflasi didapatkan nilai koefisien senilai 0,754804 yang memiliki arti apabila inflasi meningkat senilai $1 \%$ maka pertumbuhan aset akan meningkat senilai 0,754804 dengan 
dugaan variabel yang lain dianggap tetap.

4. Hasil regresi variabel suku bunga acuan bank Indonesia menunjukkan nilai koefisien senilai $-0,139233$ sehingga apabila terjadi peningkatan suku bunga senilai $1 \%$ maka pertumbuhan aset akan mengalami penurunan senilai 0,139233 dengan dugaan variabel yang lain diduga tetap.

5. Pada variabel CAR didapatkan nilai koefisien regresi senilai $-0,078257$. Hal tersebut dapat berarti apabila variabel CAR terjadi peningkatan senilai 1\% maka pertumbuhan aset akan menurun senilai 0,078257 dengan anggapan variabel lain diduga tetap.

6. Variabel NPF menunjukkan nilai koefisien regresi senilai -0,825108 dengan memiliki arti setiap terjadi peningkatan NPF senilai 1\% maka akan terjadi penurunan pada pertumbuhan total aset sebesar 0,825108 dengan anggapan variabel yang lain diduga tetap.

7. Variabel FDR menunjukkan nilai koefisien regresi senilai -8,57E-05. Hal ini memiliki arti jika terjadi peningkatan FDR senilai 1\% maka akan terjadi penurunan senilai 8,57E-05 pada pertumbuhan aset dengan anggapan variabel yang lain diduga tetap.

\subsection{Pembahasan Hasil Penelitian}

\section{Dampak PDB terhadap terhadap Perkembangan Bank Umum Syariah di Indonesia}

Variabel PDB menunjukkan hasil t-hitung sebesar 0,51 dan probabilitas 0,6087. Karena nilai t-hitung lebih rendah ketimbang nilai t-tabel serta nilai probabilitas berada diatas 0,05 maka bisa diterangkan yakni PDB tidak berpengaruh secara signifikan terhadap perkembangan bankumum syariah di Indonesia. Halini bertentangan dengan hasil yang ditemukan oleh Lubis (2016) yang menyampaikan bahwa PDB berpengaruh positif terhadap pertumbuhan aset bank syariah.

Apabila dikaji secara teoritis, hasil yang didapatkan daripenelitian yang telah dilaksanakan memberikan hasil bahwa perbankan syariah di Indonesia dalam pelaksanaanya sesuai dengan Teori Ekonomi Islam murni. Teori ini menerangkan bahwa uang pada ekonomi islam hanya digunakan sebagai alat tukar tidak sebagai alat investasi, sehingga perputaran uang harus terus dilakukan agar usaha riil dapat dilakukan sehingga nantinya terdapat manfaat yang akan didapatkan. Oleh karena itu produk-produk perbankan syariah sendiri lebih fokus pada sektor riil, hal ini dapat terlihat dengan adanya pembiayaan musyarakah maupun mudharabah, karena islam lebih memprioritaskan perputaran uang pada sektor riil.

\section{Dampak Inflasi terhadap Perkembangan Bank Umum Syariah di Indonesia}

Pengujian pada variabel inflasi mendapatkan hasil t-hitung $(1,12)<\mathrm{t}$-tabel $(1,65)$ juga probabilitas $(0,2621)>0,05$ yang memiliki arti bahwa tidak adanya pengaruh signifikan pada variabel inflasi akan perkembangan bank umum syariah di Indonesia. Pernyataan ini bertentangan denganl penelitian yang telah dilaksanakan oleh Oktavianti dan Nanda (2019) yang mendapatkan hasil bahwa terdapat pengaruh positif signifikan pada variabel inflasi terhadap pertumbuhan perbankan syariah.

Hasil yang didapatkan setelah melakukan pengujian memiliki arti yaitu pada saat bank syariah melakukan ekspansi dan menambah asetnya hal tersebut tidak akan dipengaruhi oleh kenaikan inflasi maupun penurunan inflasi yang sedang terjadi. Hal ini dapat terjadi karena pemerintah dan bank Indonesia mempunyai peranan sebagai regulator, dimana tingkat inflasi dapat dikendalikan. Para pelaku industri perbankan juga dapat meminimalisir berbagai dampak dari peruahan tingkat inflasi tersebut dengan menyusun strategi maupun tindakan tertentu yang sifatnya preventif, karena perubahan inflasi dapat diprediksi. Selain itu, pengaruh yang tidak signifikan pada variabel inflasi dapat dikatakan bahwa inflasi tidak menghambat kegiatan ekonomi syariah karena sesuai dengan teori ekonomi islam murni, dimana di dalam syariah sendiri lebih memprioritaskan perputaran uang di sektor riil dan investasi untuk melakukan aktivitas yang sifatnya produktif sehingga hal ini tidak akan menghambat perkembangan bank umum syariah dalam meningkatkan pangsa pasarnya 
(Setyowati et al., 2019).

\section{Dampak Suku Bunga Acuan BI terhadap Perkembangan Bank Umum Syariah di Indonesia}

Hasil dari uji hipotesis yang telah dilaksanakan mendapatkan hasil bahwa suku bunga acuan BI mempunyai pengaruh negative signifikan terhadap perkembangan bank umum syariah di Indonesia. Hal ini dapat ditunjukkan melalui nilai t-hitung $(-5,711)>t$-tabel $(1,65)$ serta probabilitas $(0,0000)<0,05$.

Pengaruh negatif ini dapat ditunjukkan dengan hubungan tingkat suku bunga dengan jumlah nasabah. Jika tingkat suku bunga bank konvensional meningkat maka akan mengurangi jumlah nasabah yang menabung di bank syariah. Karena jika tingkat suku bunga meningkat, maka nilai suku bunga deposito akan meningkat pula, sehingga akan terjadi penurunan pada sumber dana pihak ketiga bank syariah. PenurunanDPK dapat terjadi karena masyarakat lebih memilih untuk menabung di bank konvensional karena tingkat bunga lebih tinggi dibandingkan bank syariah sehingga apabila suku bunga turun maka perkembangan bank umum syariah akan meningkat.

Setiawan (2020) mengungkapkan bahwa nisbah bagi hasil yang rendah dapat menunjukkan bahwa nilai tambah perekonomian yang dilakukan dari pembiayaan bank syariah masih rendah dan dapat berdampak buruk pada pertumbuhan ekonomi jangka panjang. Sehingga solusi yang dapat diberikan adalah bank umum syariah perlu berusaha supaya nilai nisbah bagi hasil lebih besar dibandingkan dengan suku bunga pada bank konvensional, karena jika nilai nisbah bagi hasil bank syariah lebih besar dibandingkan tingkat suku bunga hal tersebut akan meningkatkan kepercayaan masyarakat sehingga jumlah nasabah yang menabung di bank syariah akan meningkat pula dan akhirnya akan meningkatkan total aset bank umum syariah sehingga pertumbuhan bank umum syariah pun akan mengalami peningkatan.

\section{Dampak CAR terhadap Perkembangan Bank Umum Syariah di Indonesia}

Nilai probabilitas dari variabel Capital Adequacy Ratio (CAR) memiliki nilai yang lebih besar dari 0,05 yaitu 0,1187 serta t-hitung yang di dapat lebih rendah dibandingkan t-tabel $(0,51<1,65)$. Hal ini dapat menerangkan bahwa tidak adanya pengaruh siginifikan pada variabel CAR terhadap perkembangan bank umum syariah di Indonesia. Sehingga hal ini menolak hasil dari penelitian yang dilakukan oleh Suryakusuma \& Wahyuni (2018) yang menerangkan bahwa ditemukan pengaruh positif pada variabel CAR terhadap pertumbuhan aset bank syariah.

Meskipun hasil dari penelitian yang dilakukan bertentangan dengan hasil penelitian Suryakusuma \& Wahyuni (2018), namun hasil dari penelitian yang telah dilakukan mempunyai hasil yang sama dengan penelitian yang dilaksanakanoleh Oktavianti dan Nanda (2019)yang menerangkan bahwa tidak ditemukannya pengaruh pada variabel CAR terhadap perkembangan bankumumsyariah di Indonesia. Halimatus dan Mauluddi (2018) di dalam penelitiannya menyatakan bahwa kondisi ini dapat diakibatkan karena risiko dari pembiayaan atau aset lain yang dimiliki bank tinggi, sehingga hal ini dapat mempengaruhi modal yang dimiliki oleh bank. Tingkat risiko yang tinggi dan terjadinya penurunan modal akan menurunkan nilai CAR, hal ini dapat terjadi karena modal dapat berfungsi untuk menyerap risiko-risiko yang dapat terjadi dalam kegiatan operasional.

Selain penyebab yang telah disampaikan, hal ini juga dapat dikarenakan karena bank syariah menjalankan peraturan yang diatur oleh Otoritas Jasa Keuangan (OJK) yang menyatakan bahwa pihak bank harus memenuhi CAR sebesar minimal 8\% sehingga bank selalu berusaha untuk menjaga nilai CAR tersebut. Pemenuhan CAR sesuai aturan ini dilakukan agar dapat terciptanya perbankan syariah yang bersifat dan bisa bersaing Internasional, serta dapat meningkatkan bank dalam hal menyerap risiko.

\section{Dampak NPF terhadap Perkembangan Bank Umum Syariah di Indonesia}


Nilai probabilitas yang di dapat oleh variabel Non Performing Financing (NPF) adalah senilai 0,0000 yakni lebih rendah dari 0,05 serta hasil dari t-hitung menyatakan lebih besar dibandingkan dengan t-tabel $(-4,72>1,65)$. Maka dapat dikatakan yakni pengaruh yang diberikan oleh variabel NPF terhadap perkembangan bank umum syariah di Indonesia adalah pengaruh negatif signifikan. Hal ini serupa dengan hasil dari penilitian yang dilaksanakan oleh Suryakusuma \& Wahyuni (2018) dan Djuwita \& Mohammad (2016) yang menerangkan terdapat pengaruh negatif pada variabel NPF terhadap pertumbuhan aset bank syariah.

Nilai NPF yang semakin tinggi dapat memberikan dampak pada kesehatan bank dan dapat dikatakan bahwa bank belum cukup baik dalam mengelola pembiayaannya. Jika NPF yang didapat semakin tinggi maka kerugian yang diterima pun akan semakin besar pula sehingga hal ini dapat mengurangi keuntungan yang diterima oleh bank. Apabila keuntungan bank mengalami penurunan maka total aset bank pun akan ikut menurun pula. Hasil berpengaruh negatif signifikan yang didapat dari variabel NPF ini dapat menunjukkan bahwa semakin besar nilai NPF maka akan terjadi penurunan pada total aset dan hal ini berpengaruh terhadap perkembangan bank umum syariah di Indonesia.

\section{Dampak FDR terhadap Perkembangan Bank Umum Syariah di Indonesia}

Setelah melakukan uji hipotesis didapatkan hasil bahwa variabel FDR mendapatkan hasil thitung $(-2,06)>\mathrm{t}$-tabel $(1,65)$ serta probabilitas $0,0397<0,05$. Hasil ini memiliki arti bahwa ditemukannya pengaruh negatif pada variabel FDR terhadap perkembangan bank umum syariah di Indonesia.

Dengan demikian, hasil dari penelitian yang telah dilaksanakan bertentangan dengan penelitian yang telah dijalankan oleh Djuwita \& Mohammad (2016) yang mengungkapkan bahwa adanya pengaruh positif pada variabel FDR terhadap pertumbuhan bank syariah.

Pengaruh negatif ini dapat digambarkan apabila rasio FDR meningkat sementara variabel lain dianggap tetap maka pertumbuhan aset akan mengalami penurunan. Apabila FDR meningkat maka likuiditas pada bank akan menurun dan jumlah aset lancar dan aset total pun akan mengalami penurunan. Sehingga dapat disimpulkan bahwa tidak seluruh nilai FDR yang memproyeksikan jumlah pembiayaan yang tinggi dapat menambah aset bank umum syariah, maka meskipun bank umum syariah dalam menyalurkan dananya dikatakan baik namun hal tersebut belum tentu dapat menyebabkan pertumbuhan aset pada bank umum syariah.

\section{Dampak Faktor Eksternal dan Faktor Internal terhadap Perkembangan Bank Umum Syariah di Indonesia Secara Simultan}

Hasil pengujian yang telah dilakukan dengan uji $\mathrm{F}$ mendapatkan hasil nilai $\mathrm{F}$-statistic senilai 21,90233 serta nilai probabilitas (prob F-statistic) senilai 0,000000. Hasil tersebut menerangkan bahwa nilai p-value lebih rendah dari 0,05 dan nilai F-hitung lebih besar dibandingkan nilai F-tabel (2.254722). Sehingga dapat diputuskan bahwa faktor eksternal (Produk Domestik Bruto, Suku Bunga Acuan BI dan Inflasi) dan faktor internal (Capital Adequacy Ratio, Non Performing Financing dan Financing to Deposit Ratio) secara bersama-sama mempengaruhi perkembangan bank umum syariah di Indonesia secara signifikan.

\section{Penutup}

\section{Kesimpulan}

1. Faktor eksternal yakni Suku Bunga Acuan Bank Indonesia mempengaruhi perkembangan bank umum syariah di Indonesia dengan negatif signifikan, sedangkan untuk faktor eksternal lainnya yakni PDB dan Inflasi tidak ditemukannya pengaruh yang signifikan akan 
perkembangan bank umum syariah di Indonesia.

2. Faktor internal yaitu Non Performing Financing serta Financing to Deposit Ratio memberikan pengaruh negatif signifikan akan pertumbuhan aset bank umum syariah di Indonesia, sedangkan Capital Adequacy Ratio tidak memberikan pengaruh signifikan terhadap pertumbuhan aset bank umum syariah di Indonesia.

3. Faktor eksternal (Produk Domestik Bruto, Suku Bunga Acuan BI dan Inflasi) dan faktor internal (Capital Adequacy Ratio, Non Performing Financing dan Financing to Deposit Ratio) secara bersama-sama berpengaruh signifikan terhadap Perkembangan BankUmum Syariah di Indonesia sebesar $61,02 \%$, sedangkan sisa sebesar 38,98\% lainnya disebabkan oleh pengaruh faktor lain di luar penelitian.

\section{Saran}

1. Disarankan bagi para manajemen bank untuk dapat menjaga rasio CAR sebesar minimal yang telah ditetapkan di dalam ketentuan yang berlaku, selain itu lebih selektif dalam mengeluarkan pembiayaan sehingga apabila terjadi resiko pembiayaan bermasalah hal tersebut dapat diminimalisir dengan baik, diharapkan juga bank umum syariah lebih sigap dalam menangani perubahan kebijakan karena apabila pihak manajemen dapat menangani masalah ini dengan baik maka hal tersebut dapat meningkatkan market share bank umum syariah.

2. Pemerintah dalam mengeluarkan kebijakannya diharapkan lebih memperhatikan sistem perbankan syariah, sehingga bank umum syariah dapat mempertahankan prinsip syariahnya dan dapat bersaing dengan lembaga keuangan lainnya.

3. Diharapkan pada penelitian berikutnya, peneliti berkenan untuk menambah variabel lain selain dari penelitian ini, sehingga dapat memperkuat literatur mengenai faktor-faktor yang dapat mempengaruhi perkembangan bank umum syariah di Indonesia.

\section{Daftar Pustaka}

Arifin, Z. (2009). Dasar-dasar Manajemen Bank Syariah. In Pustaka Alvabet.

Badan Pusat Statistik. (2019). Produk Domestik Bruto. https://www.bps.go.id/subject/11/produkdomestik-bruto--lapanganusaha-.ht usaha-.html\#subjekViewTab1

Bank Indonesia. (2015). Penerapan Manajemen Risiko bagi Bank Umum Syariah dan Unit Usaha Syariah. Peraturan Bank Indonesia, 1, 1-43. https://doi.org/10.1017/CBO9781107415324.004

Bank Indonesia. (2016). BI Rate. Metadata. https://www.bi.go.id/id/statistik/metadata/seki /Documents/8_Suku_Bunga_Indo_DPM SEKI_2016 (Indonesia) new.pdf

Boediono. (1985). Teori Pertumbuhan Ekonomi. BPFE.

Djuwita, D., \& Muhammad, A. F. (2016). Pengaruh Total DPK, FDR, NPF dan ROA terhadap Total Asset Bank Syariah di Indonesia. Jurnal Kajian Ekonomi Dan Perbankan Syari'ah, 8(1), 281297.

GIFR. (2020). Islamic Finance Country Index-IFCI 2019. Global Islamic Finance Report 2019, 49-79.

Halimatus, S., \& Mauluddi, H. A. (2018). Bank Muamalat Indonesia Profitability Analysis: Study Of The Effects Of Capital, Asset Quality, Earnings And Liquidity. Jurnal Ekonomi Dan Bisnis Terapan, 14(1), 69-81.

Hastasari, R. (2019). Pengaruh Ekonomi Makro Dan Kinerja Manajemen Terhadap Return on Assets (Roa) Perbankan Syariah. Widya Cipta - Jurnal Sekretari Dan Manajemen, 3(1), 115-122. https://doi.org/10.31294/widyacipta.v3i1.5109

Hendratno, \& Winarno, A. (2019). Pengaruh Variabel Eksternal Terhadap Return On Aset (Studi 
Kasus Bank Umum Syariah Yang Terdaftar Di BEI, Periode 2012-2019). Jurnal Manajemen Indonesia, 19(2), 196-207.

IFSI. (2019). Stability Report 2019. In The edge markets. https://www.theedgemarkets.com/article /malaysias-islamic-banking-industry-will-achieve-40-market-share-2020-says-aibim

Jaya, W. K. (2001). Ekonomi Industri. BPFE.

Lubis, A. F. (2016). Analisis Pertumbuhan Total Asset Perbankan Syariah Di Indonesia. Nusantara (Jurnal Ilmu Pengetahuan Sosial), 1.

Mankiw, N. G. (2007). Makroekonomi (Edisi 6). Erlangga.

Mankiw, N. G. (2009). Macroeconomics, 7th Edition. Worth Publishers.

Oktavianti, E., \& Nanda, S. T. (2019). Analisis Pengaruh CAR, NPF, BOPO, Inflasi, Produk Domestik Bruto Dan Suku Bunga BI Terhadap Pertumbuhan Perbankan Syariah. Ilmiah Ekonomi Dan Bisnis, 16(1), 46-55.

Rasyidin, D. (2016). Financing To Deposit Ratio (FDR) Sebagai Salah Satu Penilaian Kesehatan Bank Umum Syariah (Study Kasus Pada Bank BJB Syariah Cabang Serang). Islamiconomic: Jurnal Ekonomi Islam, 7(1), 19-36. https://doi.org/10.32678/ijei.v7i1.34

Samuelson, P. A., \& Nordhaus, W. D. (2004). Ilmu Makroekonomi (Edisi 7). Penerbit Erlangga.

Setiawan, S. (2018). Determinan Penentu Pertumbuhan Dana Pihak Ketiga Perbankan Syariah di Indonesia. Jurnal Maps (Manajemen Perbankan Syariab), 1(2), 1-9.

Setiawan, I. (2020). Analisis Peran Perbankan terhadap Pertumbuhan Ekonomi di Indonesia: Bank Syariah Versus Bank Konvensional. Jurnal Akuntansi, Ekonomi Dan Manajemen Bisnis, 8(1), 5260. https://doi.org/10.30871/jaemb.v8i1.1649

Setyawati, I. (2015). Determinan Pertumbuhan Total Aset Dan Pangsa Pasar Pada Perbankan Syariah. Mediastima Tabun, XXI(2), 80-115.

Setyowati, D. H., Sartika, A., \& Setiawan, S. (2019). Faktor-Faktor Yang Mempengaruhi Pangsa Pasar Industri Keuangan Syariah Non-Bank. Jurnal Iqtisaduna, 5(2), 169. https://doi.org/10.24252/iqtisaduna.v5i2.10986

Siamat, D. (2005). Manajemen Lembaga Keuangan. LPFE UI.

Soemarso, S. . (2005). Akuntansi: Suatu Pengantar 2 (Edisi 5). Salemba Empat.

Suadi, A., \& Candra, M. (2016). Politik Hukum: Perspektif Hukum Perdata dan Pidana Islam serta Ekonomi Syariah. Prenada Media.

Sukirno, S. (1994). Pengantar Ekonomi Makro. PT Raja Grafindo Persada.

Suryakusuma, K. H., \& Wahyuni, A. N. (2018). Dampak Makro Ekonomi Dan Faktor Internal Terhadap Kinerja Keuangan Bank Umum Syariah Di Indonesia. Jwem Stie Mikroskil.

Tripuspitorini, F. A., \& Setiawan, S. Pengaruh Faktor Makroekonomi Terhadap Pertumbuhan Dana Pihak Ketiga Pada Bank Umum Syariah di Indonesia. Jurnal Riset Akuntansi dan Kenangan, 8(1), 121-132. 